\title{
Epstein-Barr virus BARF1-induced NFkB/miR-146a/SMAD4 alterations in stomach cancer cells
}

\author{
Dong Ha Kim ${ }^{1,2, *}$, Mee Soo Chang ${ }^{3, *}$, Chan Jin Yoon ${ }^{1,2}$, Jaap M. Middeldorp ${ }^{4}$, Olivia \\ M. Martinez ${ }^{5}$, Sun-ju Byeon ${ }^{3}$, Sun Young Rha ${ }^{6}$, Sung Han Kim ${ }^{1,2}$, Yang Soo Kim ${ }^{1,2}$, \\ Jun Hee Woo W,2 $^{1,2}$ \\ ${ }^{1}$ Asan Institute for Life Sciences, Department of Infectious Diseases, Asan Medical Center, University of Ulsan College of \\ Medicine, Seoul, Republic of Korea \\ ${ }^{2}$ Department of Infectious Diseases, Asan Medical Center, University of Ulsan College of Medicine, Seoul, Republic of Korea \\ ${ }^{3}$ Department of Pathology, Seoul National University Boramae Hospital, Seoul National University College of Medicine, Seoul, \\ Republic of Korea \\ ${ }^{4}$ Department of Pathology, VU University Medical Center, Amsterdam, the Netherlands \\ ${ }^{5}$ Department of Surgery/Division of Abdominal Transplantation, Stanford University School of Medicine, Stanford, CA, USA \\ ${ }^{6}$ Department of Internal Medicine, Yonsei University College of Medicine, Seoul, Republic of Korea \\ * These authors have contributed equally to this work
}

Correspondence to: Mee Soo Chang, email: meesooch@snu.ac.kr Jun Hee Woo, email: junheewoo@amc.seoul.kr

Keywords: Epstein-Barr virus, BARF1, NFKB, miR-146a, SMAD4

Received: January 11, 2016 Accepted: May 12, $2016 \quad$ Published: July 09, 2016

\section{ABSTRACT}

Epstein-Barr virus (EBV)-encoded BamHI-A rightward frame 1 (BARF1) is a putative viral oncogene in EBV-infected stomach cancer. The aim of the present study was to investigate BARF1-induced cellular protein and microRNA alterations. In this study, BARF1-expressing stomach cancer cells showed a high rate of proliferation, high levels of NFKB, and miR-146a upregulation, which was reversed by NFKB knockdown. During BARF1-induced NFKB upregulation, hCSF1 receptor level was unchanged. Knockdown of BARF1 in the naturally EBV-infected YCCEL1 stomach cancer cells suppressed cell proliferation, and downregulated NFKB and miR-146a. SMAD4 was identified as a miR-146a target and was downregulated in BARF1-expressing cells, whereas SMAD4 expression was restored by anti-miR-146a. Knockdown of BARF1 in YCCEL1 cells upregulated SMAD4, and this effect was reversed by miR-146a overexpression. Transfection of BARF1-expressing cells with pCEP4SMAD4 abolished the cell proliferating effect of BARF1. In stomach cancer tissues, miR-146a was expressed at higher levels, and more frequent NFKB nuclear positivity immunohistochemically, but not of SMAD4 nuclear loss was found in the EBV-positive group compared with the EBV-negative group. In conclusion, EBV-encoded BARF1 promotes cell proliferation in stomach cancer by upregulating NFKB and miR-146a and downregulating SMAD4, thereby contributing to EBV-induced stomach cancer progression.

\section{INTRODUCTION}

In 2014, molecular analytic data from The Cancer Genome Atlas (TCGA) (http://cbioportal.org) corroborated that Epstein-Barr virus (EBV)-associated stomach cancer is a specialized subset of stomach cancer [1]. EBV is responsible for various human lymphoid and epithelial malignancies $[1,2,3]$ including EBV-infected stomach cancer, which was first reported in 1990 [4]. Currently, stomach cancer is the most frequent EBV-associated malignancy $[5,6]$. Stomach cancer caused by EBV infection accounts for approximately $5-10 \%$ of all stomach cancers worldwide irrespective of cancer incidence [1, 5-13]. Over the last 25 years, accumulating evidence 
has shown that EBV infection may directly contribute to the development of stomach cancer. EBV-positive gastric carcinomas are characterized by the monoclonal proliferation of EBV-infected cancer cells [14], global $\mathrm{CpG}$ island methylation of cancer-related genes [15], unique methylation patterns leading to CDKN2A (p16) downregulation $[1,16]$, and hyperactive T-cell activation $[1,11]$. In addition, EBV-positive stomach cancer shows characteristic clinicopathological features, including a higher prevalence in male patients, predominant localization to the proximal stomach, a tendency towards a poorly differentiated histologic type and a diffuse Laurentype, the presence of lymphoid stroma [1,9-11], and a unique cellular protein expression profile [12].

The mechanism by which EBV causes stomach cancer remains unclear. EBV-encoded BamHI-A rightward frame 1 (BARF1) was suggested to function as a viral oncogene (oncogenic initiator or oncogenic cofactor) in EBV-positive stomach cancer [5, 17-19]. It has been demonstrated that BARF1 exists in all of EBV-positive stomach cancer tissues with a specialized BARF1nucleic acid sequence-based amplification (NASBA) method using frozen tissue [19]. Wei et al first described recombinant BARF1-induced oncogenic activities, such as the tumorigenic transformation of mouse fibroblasts and tumor formation in new-born rats [20]. BARF1 has sequence homology with colony stimulating factor-1 receptor (hCSF1 receptor), and BARF1 binds to hCSF1 (macrophage-colony stimulating factor), similar to the binding between hCSF1 and hCSF1 receptor, which modulates the fates of immune-related cells such as macrophages [18, 21, 22]. EBV-encoded latent membrane protein (LMP) $2 \mathrm{~A}$ is expressed on almost all EBV-positive human cancers [23], and the role of LMP2A in EBVinduced stomach carcinogenesis has been analyzed $[6,10$, 24, 25]. LMP1 is an established viral oncogene in EBVinfected malignant lymphoma and nasopharyngeal cancer $[3,26]$; however, LMP1 is not expressed in EBV-infected stomach cancer due to promoter methylation $[3,6,10]$.

MicroRNAs (miRNAs) are endogenous small (19-22 nucleotides) non-coding RNAs that function as post-transcriptional regulators of gene expression by binding to complementary sites in the $3^{\prime}$ untranslated region (3' UTR) of target mRNAs [27, 28]. miRNAs have been implicated in the regulation of various biological processes such as inflammation, infection, immune responses and tumorigenesis [28-30]. The established viral oncogene LMP1 upregulates several cellular miRNAs in different human malignancies [31-36]. To the best of our knowledge, BARF1-induced cellular miRNA changes have not yet to be observed in human malignancies. We previously showed that secreted BARF1 upregulated nuclear factor $\kappa \mathrm{B}(\mathrm{NF} \kappa \mathrm{B})$ in an autocrine and paracrine manner in stomach cancer [5]. NFאB induces miR-146a expression, and the promoter region of miR-146a contains $\mathrm{NF \kappa B}$ binding sites $[29,33,37,38]$. Furthermore, miR-146a can directly downregulate several genes including 'similar to mothers against decapentaplegic homologue 4' (SMAD4) [39, 40], STAT-1, and IRF-5 [29]. Of these, the SMAD4 protein is related to NFkB activity [41, 42]. SMAD4 is a central mediator of the transforming growth factor beta (TGF $\beta$ ) signaling pathway. In this pathway, TGF $\beta$ activation leads to the formation of a heteromeric complex between activated SMAD2/ SMAD3 and SMAD4, which translocates into the nucleus, and affects transcriptional activity [43-45]. The involvement of SMAD proteins in EBV-associated oncogenesis has been described previously. EBV-encoded LMP1 antagonizes the TGF $\beta-S M A D$ pathway through NFאB signaling $[41,46]$, and EBV-encoded EBNA1 suppresses the interaction of SMAD2 with SMAD4 [47].

The objective of the present study was to investigate EBV-encoded BARF1-induced changes such as cell proliferation and cellular miRNA and protein expression.

\section{RESULTS}

\section{Secreted BARF1 was detected in BARF1- expressing SNU 601 cells}

BARF1 transcripts were detected in BARF1expressing cells (SNU601 BARF1 and SNU216 BARF1) and in the naturally EBV-infected stomach cancer cell lines SNU719 [7, 8] and YCCEL1 [48], but not in SNU601 and SNU216 mock cells (transfected with an empty vector) (Figure 1A). BARF1 protein was almost undetectable in untreated SNU601 BARF1 cells and weakly detected in untreated SNU216 BARF1, SNU719 and YCCEL1 cells; however, BARF1 accumulated in cells treated with Brefeldin A (to block protein secretion), suggesting that translated BARF1 is mainly secreted (Figure 1B).

\section{BARF1 promoted stomach cancer cell proliferation}

Both SNU601 BARF1 cells and SNU 216 BARF1 cells showed higher rates of cell proliferation than their mock cells $(P<0.05$; Figure 1C). Conversely, YCCEL1 cells transfected with siRNA against BARF1 (siBARF1) showed a lower rate of cell proliferation than scrambled siRNA (siSCR)-transfected YCCEL1 cells (Figure 1C).

\section{BARF1 upregulated miR-146a-5p in an NFkB- dependent manner}

To examine the mechanism underlying the cell proliferation effect of BARF1, we analyzed the potential role of $\mathrm{NF} \kappa \mathrm{B}$. NFKB luciferase activity was higher in SNU601 BARF1 cells than in SNU601 mock cells $(P<0.05)$, and NFKB activity was lower in siBARF1-transfected YCCEL1 cells than in scrambled siRNA-transfected control YCCEL1 cells $(P<0.01)$ 
(Figure 2A). The levels of phospho-hCSF1 receptor and hCSF1 receptor were unaltered irrespective of BARF1 presence or knockdown, while BARF1 induced NF $\kappa B$ and miR-146a-5p upregulation (Figure 2B). We then examined the association of miR-146a-5p, a cellular miRNA, with NFkB. miR-146a-5p levels were significantly higher in SNU601 BARF1 cells than in SNU601 mock cells $(P<0.01)$, and miR-146a-5p was downregulated in siBARF1-transfected YCCEL1 cells compared with scrambled siRNA-transfected control $(P<0.01)$ (Figure 2C). Transfection of SNU601 BARF1 cells with NFKB RelA-specific siRNA suppressed the BARF1-induced upregulation of miR-146a-5p (Figure 2D). These results indicate that BARF1 increased the levels of NFkB RelA and upregulated miR-146a-5p expression in an NFkB-dependent manner.

A

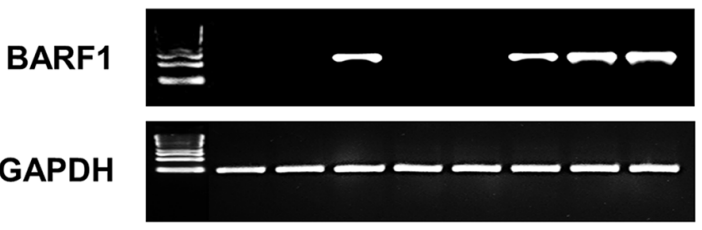

B

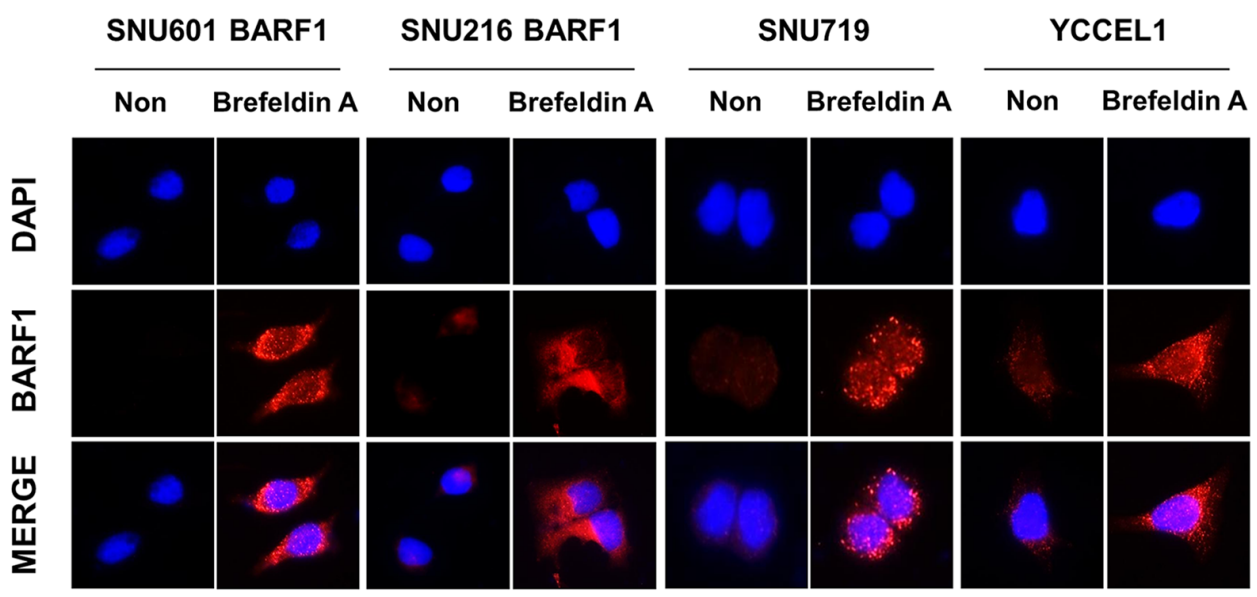

C
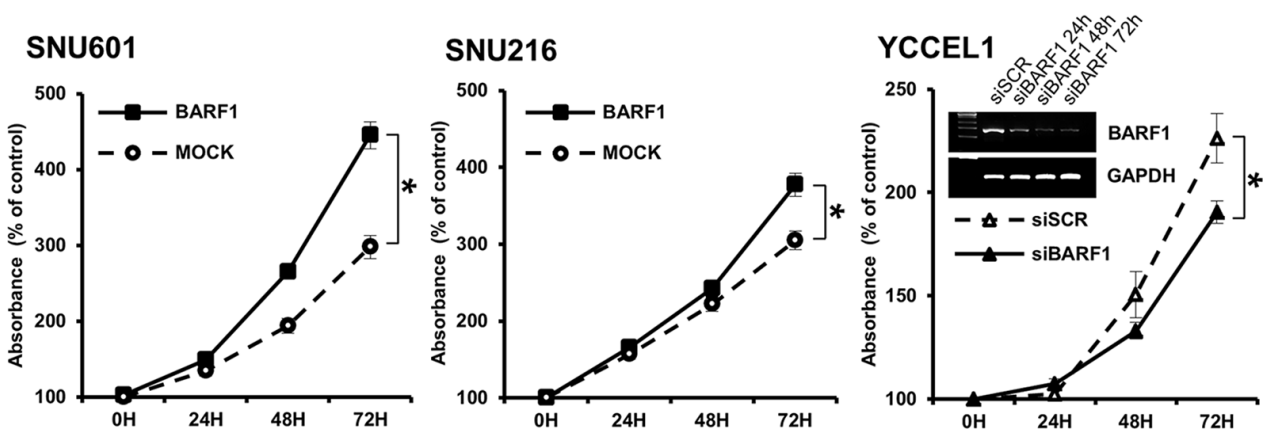

Figure 1: EBV BARF1 protein was mainly secreted and promoted cell proliferation. (A) BARF1 mRNA was detected in SNU601 BARF1 and SNU216 BARF1 cells (stable transfection with BARF1) and in naturally Epstein-Barr virus (EBV)-infected stomach cancer cells (SNU719 and YCCEL1), whereas it was undetectable in SNU601 mock cells and SNU216 mock cells. (B) As seen by fluorescence microscopy, BARF1 protein was hardly observed in SNU601 BARF1 cells and was weakly detected in SNU216 BARF1, SNU719 and YCCEL1 cells, whereas BARF1 protein accumulated in cells that were treated with Brefeldin A. BARF1 antibody (MAb 6F4) was labeled in red, and nuclei were counterstained with DAPI (blue). (C) Cell proliferation was higher in SNU601 BARF1 and SNU216 BARF1 cells than in SNU601 mock cells and SNU216 mock cells, respectively, and lower in YCCEL1 cells transfected with BARF1specific siRNA (siBARF1) than in YCCEL1 cells transfected with scrambled siRNA (siSCR) $\left({ }^{*} P<0.05\right)$. All experiments were performed in triplicate. 
A

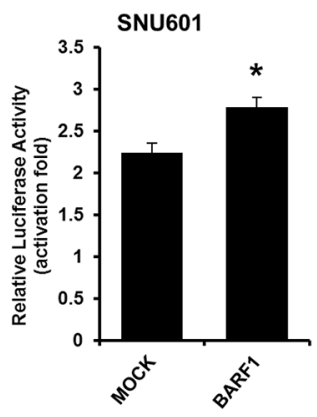

B

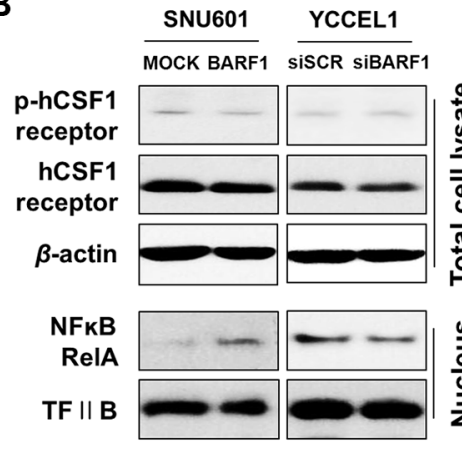

C

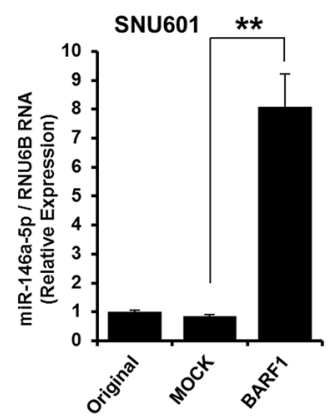

D

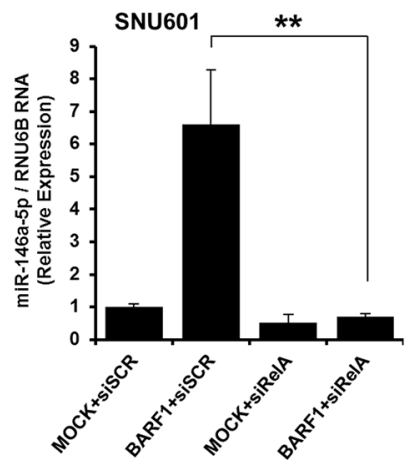

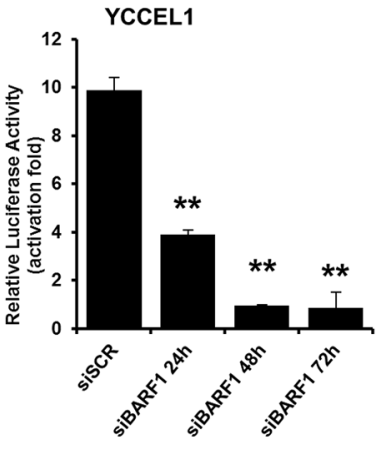

SNU601

YCCEL1
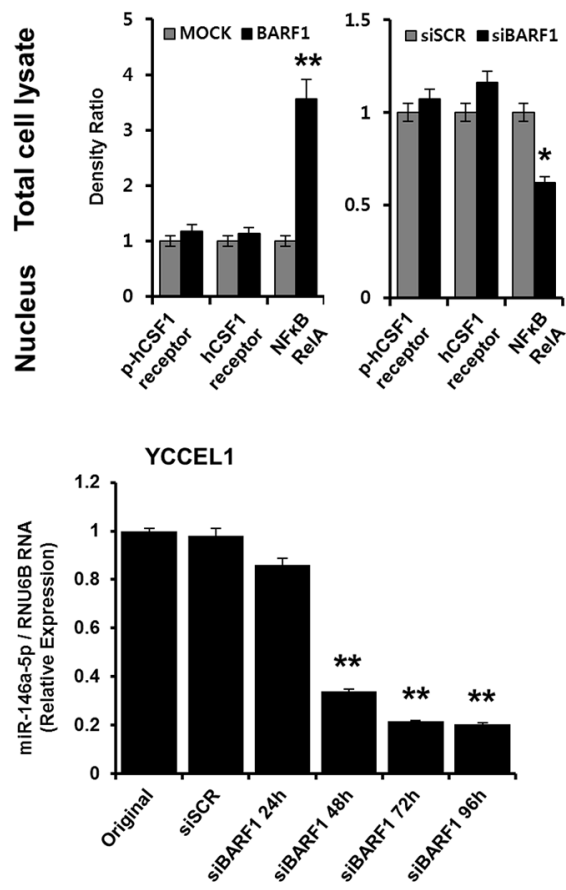

Figure 2: BARF1 upregulated miR-146a-5p in an NFkB-dependent manner. (A) Cells were transfected with an NFкBdependent luciferase reporter together with Renilla luciferase. After $72 \mathrm{~h}, \mathrm{NF \kappa B}$ activity was determined using a dual-luciferase assay. SNU610 BARF1 cells demonstrated higher NFKB transcriptional activity than SNU601 mock cells $(* P<0.05)$. YCCEL1 cells transfected with $20 \mathrm{nM}$ BARF1-specific siRNA (siBARF1) showed lower NFKB transcriptional activity than YCCEL1 cells transfected with scrambled siRNA (siSCR) $(* * P<0.01)$. (B) Phospho-hCSF1 receptor and hCSF1 receptor showed similar levels irrespective of BARF1 presence or knockdown, whereas NFKB RelA and miR-146a-5p increased in response to BARF1. (C) TaqMan quantitative real-time RT-PCR showed higher miR-146a-5p levels in SNU601 BARF1 cells than in SNU601 mock cells or untransfected SNU601 cells ( $* * P<0.01)$. Conversely, miR-146a-5p expression was markedly decreased in YCCEL1 cells transfected with BARF1-specific siRNA (siBARF1) compared with YCCEL1 cells transfected with scrambled siRNA (siSCR) or untransfected YCCEL1 cells $(* * P<0.01$ ). (D) SNU601 BARF1 cells were transfected with $20 \mathrm{nM} \mathrm{NF \kappa B} \mathrm{RelA-specific} \mathrm{siRNA} \mathrm{(siRelA)} \mathrm{or} \mathrm{scrambled} \mathrm{siRNA} \mathrm{(siSCR).} \mathrm{BARF1-induced} \mathrm{miR-146a-5p} \mathrm{upregulation}$ was neutralized by NFKB RelA inhibition $(* * P<0.01)$. All experiments were performed in triplicate. 


\section{BARF1 downregulated SMAD4 in a miR-146a- 5p-dependent manner, and SMAD4 was a direct target of miR-146a-5p in stomach cancer cells}

To identify targets of miR-146a-5p, we used the prediction algorithm TargetScan Human 6.2 (http://www. targetscan.org), which showed that the 3' UTRs of 200 mRNAs contained potential miR-146a-5p target sites. Among them, IL-1 receptor-associated kinase-1 (IRAK1) and SMAD4 were selected because of their role in NFKB activation $[41,42,50]$. Because BARF1 downregulated SMAD4 protein but had no effect on the level of IRAK1 (Supplementary Figure S2), we selected SMAD4 as a target of miR-146a-5p for subsequent analyses. miR146a-5p knockdown by transfection with anti-miR-146a$5 p$ restored SMAD4 protein levels in SNU601 BARF1 cells (Figure 3A). In YCCEL1 cells, siRNA-mediated silencing of BARF1 upregulated SMAD4 protein, whereas transfection with the miR-146a-5p mimic downregulated SMAD4 (Figure 3B). Furthermore, transient transfection of SNU601 BARF1 cells with the SMAD4 3' UTR plasmid along with miR-146a-5p led to a significant decrease in relative luciferase activity, compared with the negative control (empty vector) along with miR-146a-5p (Figure 3C). The levels of SMAD2 and SMAD3 were not affected by BARF1 (Figure 3D).

\section{BARF1 downregulated nuclear SMAD4}

Immunofluorescence analysis showed that nuclear SMAD4 protein levels were decreased in SNU601 BARF1 cells. Conversely, YCCEL1 cells transfected with siBARF1 showed increased nuclear SMAD4 protein levels (Figure 4A). This decrease in nuclear SMAD4 protein levels were confirmed via western blotting of nuclear protein extracts $(P<0.05)$ (Figure 4B).

\section{SMAD4 neutralized BARF1-induced cell proliferation}

The rate of cell proliferation was lower in SNU601 BARF1 cells transfected with pCEP4-SMAD4 than in SNU601 BARF1 cells transfected with empty vector $(P<0.01)$, indicating that ectopic expression of SMAD4 counteracted the effect of BARF1 on promoting cell proliferation (Figure 4C). These results suggest that SMAD4 downregulation is critical for cell proliferation in BARF1-expressing cells.

\section{Verification of miR-146a-5p upregulation and NFкB immunohistochemical expression in EBV-positive stomach cancer tissues}

According to the miRNA microarray analysis, 139 cellular miRNAs were differentially expressed with a 1.5fold difference between EBV-positive and EBV-negative stomach cancer tissues (Figure 5A). Thirty-one cellular miRNAs including miR-146a-5p were upregulated and 108 were downregulated in EBV-infected versus EBV-negative stomach cancer tissues (Supplementary Figure S3). The upregulation of miR-146a-5p in EBV-positive stomach cancer tissues was validated using TaqMan quantitative real-time RT-PCR (Figure 5B).

Additionally, in stomach cancer tissue surgically resected in 2012, miR-146a-5p was highly expressed in the EBV-positive stomach cancer group $(n=14)$ compared with the EBV-negative stomach cancer group $(n=19)$ (Figure 5C). Immunohistochemically, NFkB expression was more frequently observed with a marginal significance $(P=0.080)$ in the EBV-positive group, but not SMAD4 loss (Table 1).

\section{SMAD4 nuclear loss tended to be associated with} poor prognosis in EBV-positive, but not EBVnegative stomach cancer patients

For the patient survival analysis, we chose stomach cancers that were surgically resected in 2000 2005. The mean follow-up period for patient outcome was 68 months (median: 77 months). Of 328 cases, thirty cases were EBVpositive and 298 were EBV-negative (Supplementary Table S1). Immunohistochemical analysis showed SMAD4 nuclear loss in 10 of $30 \mathrm{EBV}$-positive cancer patients, of whom five (50\% of SMAD4 loss/ EBV-positive) died. Meanwhile, SMAD4 nuclear loss was observed in 81 cases in the EBV-negative group, of whom 30 patients $(37 \%$ of SMAD4 loss/ EBV-negative) were dead. Statistically, the SMAD4 nuclear loss group tended to be associated with a worse survival rate compared with the SMAD4 preservation group among EBV-positive stomach cancer patients, but not statistically significant $(P=0.08)$, and SMAD4 showed no prognostic implication among EBVnegative stomach cancer patients (Table 2 and Figure 6).

\section{DISCUSSION}

The results of the present study indicate that EBVencoded BARF1 promotes cell proliferation in stomach cancer through a mechanism involving $\mathrm{NF} \kappa \mathrm{B}$ and miR146a-5p upregulation and SMAD4 downregulation. Previous work from our group showed that NFאB RelA protein expression is higher in EBV-positive than in EBV-negative stomach cancer $[5,7,8]$, and that BARF1 promotes stomach cancer cell proliferation by upregulating $\mathrm{NF} \kappa \mathrm{B}$ [5]. Since then, we have been further searching for the molecular link between BARF1 and cell proliferation. The present study showed that BARF1 upregulated $\mathrm{NF} \kappa \mathrm{B}$ and induced NF $\kappa$ B-dependent miR-146a-5p upregulation. Currently, no studies have investigated EBV-encoded BARF1-induced cellular miRNA alterations; Motsch et al. showed that EBV-encoded LMP1 upregulates miR-146a in an NFkB-dependent manner [35], which is consistent with 
A

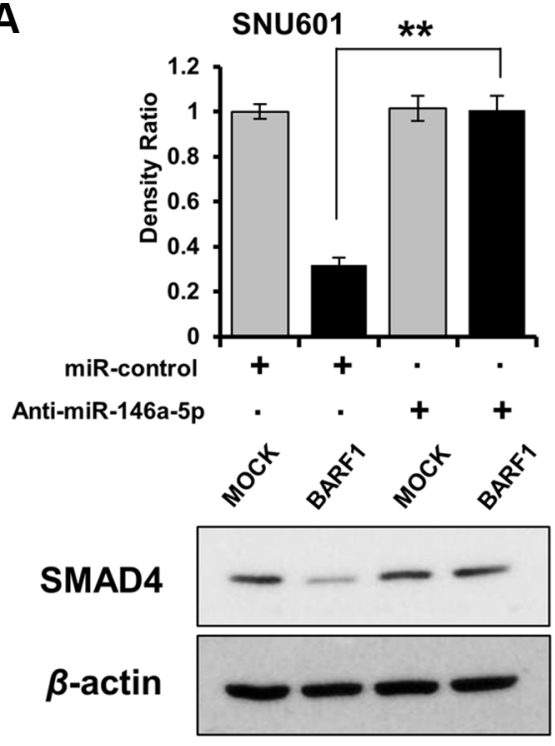

C

Position 390-397

of SMAD4 3'UTR 5'...UUUUAAAGgCAgAgAAgUUCUCA. I I I IIIIIIII

hsa-miR-146a-5p 3' UUGGGUACCUUAAGUCAAGAGU
B

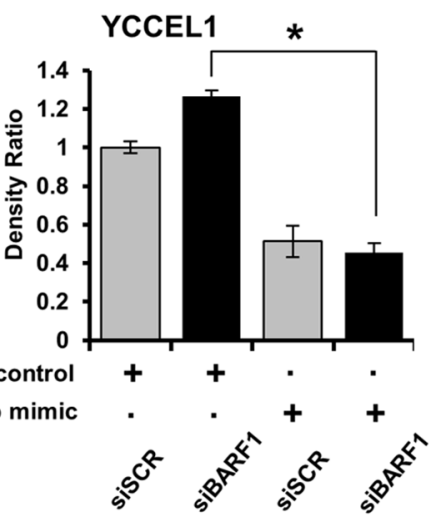

SMAD4



$\beta$-actin

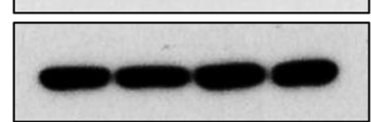

SNU601 BARF1

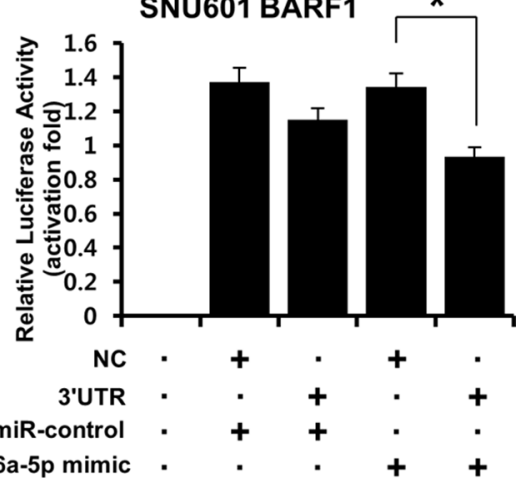

SNU601

YCCEL1

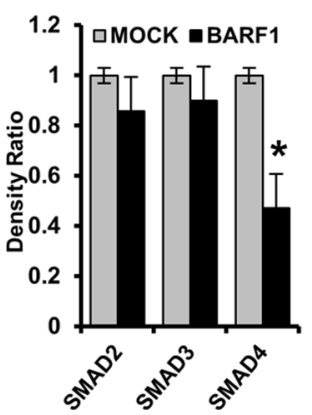

Figure 3: BARF1 downregulated SMAD4 in a miR-146a-5p-dependent manner, and SMAD4 was a direct target of miR-146a-5p. (A) SMAD4 protein expression in SNU601 BARF1 cells was measured via western blotting after transfection with a miR146a-5p inhibitor (anti-miR-146a) or a scrambled miRNA control (miR-control). SMAD4 protein level was downregulated in SNU601 BARF1 cells, and was restored by miR-146a-5p inhibition $(* P<0.05)$. (B) YCCEL1 cells (naturally EBV-infected stomach cancer) were transfected with $20 \mathrm{nM}$ siRNAs (BARF1-specific or scrambled) and $50 \mathrm{nM}$ miRNAs (miR-146a-5p mimic or miR-control). SMAD4 was upregulated in YCCEL1/siBARF1 cells and downregulated by the miR-146a-5p mimic $(* P<0.05)$. (C) The 8 -mer sequence homology between miR-146a-5p and the $3^{\prime} \mathrm{UTR}$ of SMAD4 mRNA is shown. The mRNA transcript sequences were extracted from the website (http://www.ensembl.org). The luciferase assay revealed reduced reporter activity after co-transfection of SMAD4 3'UTR and miR-146a$5 p$ in SNU601 BARF1 cells, compared with co-transfection of a negative control (NC, empty vector) and miR-146a-5p $(* P<0.05)$. All experiments were performed in triplicate. (D) BARF1 downregulated SMAD4 in total cell lysates, but had no effect on SMAD2 or SMAD3 expression. The bar graph shows the ratio of SMAD normalized to $\beta$-actin as determined by optical density measurement $\left({ }^{*} P<0.05\right)$. All experiments were performed in triplicate. 
Table 1: Comparison of NF $\mathrm{B}$ RelA, miR-146a-5p and SMAD4 between Epstein-Barr viruspositive and Epstein-Barr virus-negative stomach cancer

\begin{tabular}{|c|c|c|c|}
\hline & EBV-positive & EBV-negative & \\
\hline & $(n=14)$ & $(n=19)$ & $P$ value \\
\hline $\mathrm{NF} \kappa \mathrm{B}$ RelA & & & 0.080 \\
\hline negative & $9(67 \%)$ & $17(90 \%)$ & \\
\hline positive & $5(33 \%)$ & $2(10 \%)$ & \\
\hline miR-146a-5p & & & 0.033 \\
\hline mean / median & $148.5 / 102.3$ & $67.4 / 60.4$ & \\
\hline (range) & $(38.0 \sim 483.6)$ & $(13.0 \sim 146.4)$ & \\
\hline SMAD4 & & & 0.580 \\
\hline loss & $7(50 \%)$ & $10(53 \%)$ & \\
\hline preserved & $7(50 \%)$ & $9(47 \%)$ & \\
\hline
\end{tabular}

Table 2: Differential effect of SMAD4 on patient survival in Epstein-Barr virus-positive and Epstein-Barr virus-negative stomach cancer

\begin{tabular}{|c|c|c|c|}
\hline \multicolumn{2}{|c}{ SMAD4 nuclear loss } & SMAD4 preserved \\
\hline EBV-positive $(n=30)$ & 10 & 20 & $P$ value \\
\hline Dead & $5(50 \%)$ & $4(20 \%)$ & 0.08 \\
\hline Alive & $5(50 \%)$ & $16(80 \%)$ & \\
\hline EBV-negative $(n=298)$ & 81 & 217 & $P$ value \\
\hline Dead & $30(37 \%)$ & $85(39 \%)$ & 0.76 \\
\hline Alive & $51(63 \%)$ & $132(61 \%)$ & \\
\hline
\end{tabular}

the results of the present study regarding BARF1-induced $\mathrm{NF \kappa B} / \mathrm{miR}-146 \mathrm{a}$ upregulation. Unfortunately, the BARF1induced NFKB /miR-146a /SMAD4 axis observed in cell line was not clearly recapitulated in tissues. BARF1 protein is expressed within EBV-positive tumor cells, after that, almost completely secreted out of tumor cells [18, 21, 22], and this was attested in the present study using a secretion blocker in cell lines. Accordingly, it is challenging to directly detect BARF1 protein in tissue sample. Instead, zur Hausen et al. demonstrated the existence of BARF1 [18, 21, 22]. in EBV-positive stomach cancer tissue using a BARF1 nucleic acid sequence-based amplification (NASBA) method [19]; thus, EBV-positive stomach cancer is thought to belong to a specialized EBV latency type I expressing BARF1 [3]. In addition, there may be limits to pursuing BARF1-specific effects on $\mathrm{NF} \kappa \mathrm{B}$, miR-146a and SMAD4 in tissues, as cancer-related cellular proteins are likely controlled by intricate pathways in cancer tissues. As such, BARF1 may have a restricted effect on $\mathrm{NF} \kappa \mathrm{B}$, miR146a and SMAD4 in tissue.

The effect of BARF1 on NFkB and miR-146a in SNU601 BARF1 and naturally EBV-infected YCCEL1 cells may occur via intracellular signaling, rather than via the secretory pathway. The activation effect seems to be mediated by the N-terminal 1-20 AA domain of BARF1, which remains intracellular [18]. This idea is supported by the fact that $\mathrm{NF \kappa B}$ and miR-146a levels decreased dramatically following BARF1-specific siRNA transfection in the present study. The hCSF1 receptor might not be involoved in the process of BARF1induced NFKB and miR-146a-5p upregulation, because phospho-hCSF1 receptor and hCSF1 receptor levels were unchanged during $\mathrm{NF \kappa B}$ and miR-146a-5p upregulation (Figure 2), and hCSF1 receptor blocking did not influence BARF1-induced NFKB upregulation in the present study (Supplementary Figure S4).

The present study suggests that BARF1 suppressed SMAD4 through NFkB-dependent miR-146a upregulation in stomach cancer cells. Previous studies found that the established viral oncogene LMP1 inhibits the transcriptional activity of SMAD via NFKB activation [46]. Moreover, the present study identified SMAD4 as a direct target of miR-146a in SNU601 BARF1 cells, providing the first experimental evidence in stomach cancer cells. 
A

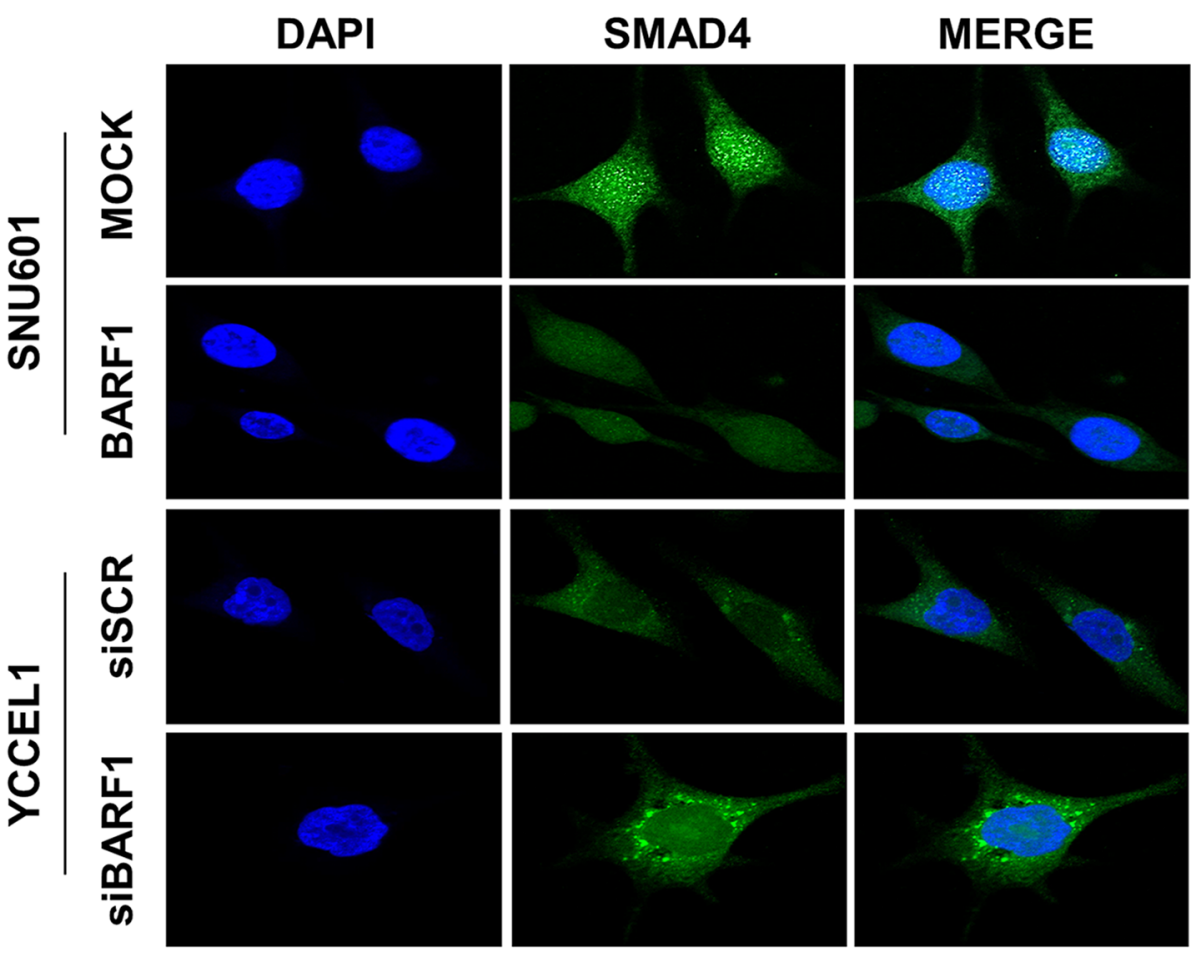

B
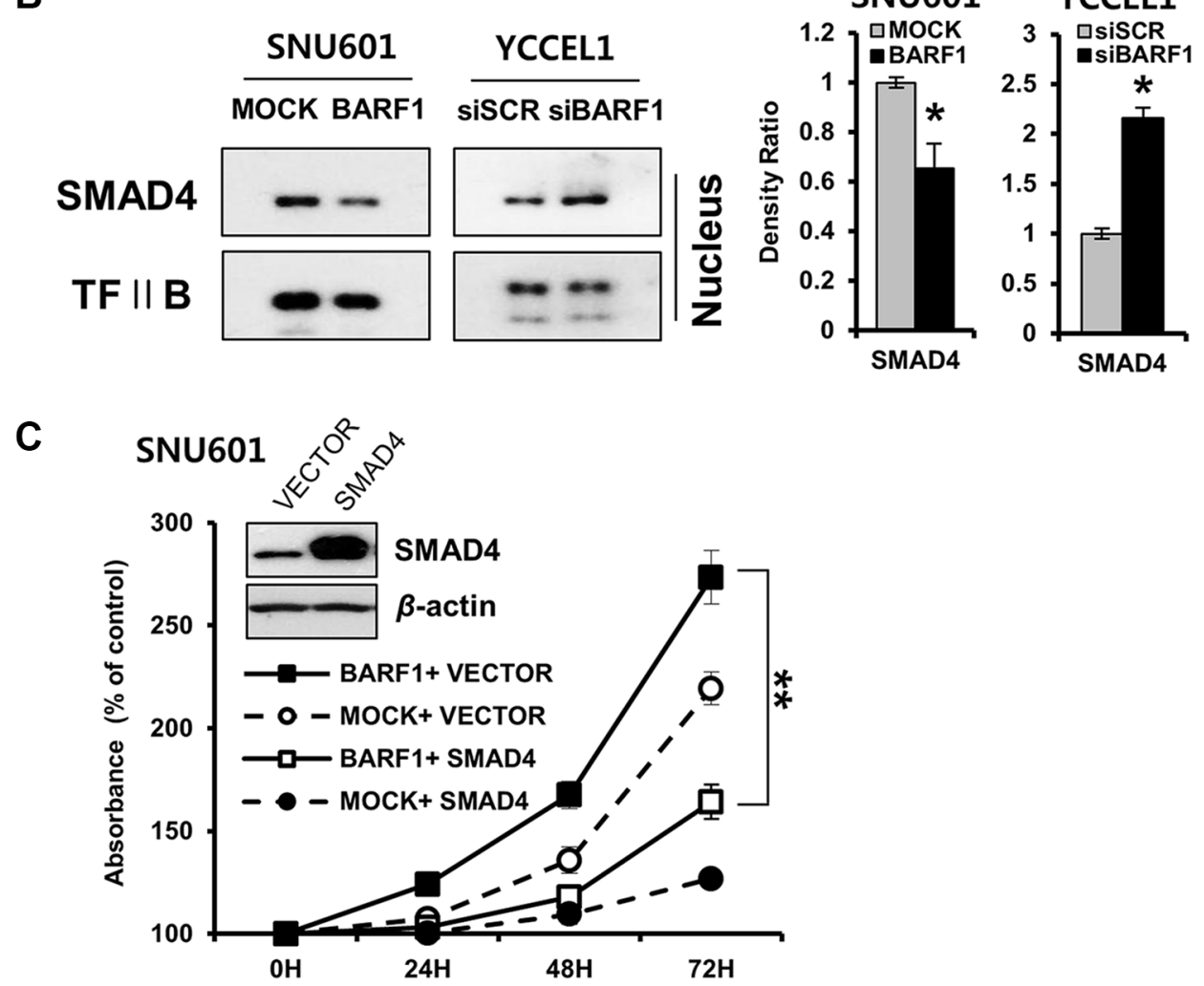

Figure 4: BARF1-mediated down regulation of nuclear SMAD4, and the effect of SMAD4 on cell proliferation. (A) Immunofluorescence was visualized via confocal microscopy. BARF1 attenuated nuclear SMAD4 in SNU601 BARF1 cells, whereas BARF1 inhibition augmented nuclear SMAD4 in YCCEL1 cells transfected with siBARF1. Cells were labeled with SMAD4 antibody (green), and nuclei were counterstained with DAPI (blue). (B) Western blotting of nuclear extracts confirmed the BARF1-mediated downregulation of nuclear SMAD4 $(* P<0.05)$. TFII B was used as a loading control. (C) SNU601 BARF1 and SNU601 mock cells were transfected with pCMV-SMAD4 (SMAD4) or pCMV-empty vector (VECTOR). Cell proliferation was suppressed by pCMV-SMAD4 transfection compared with cells transfected with empty vector $(* * P<0.01)$. All experiments were performed in triplicate. 
Xiao et al. previously detected miR-146a upregulation in stomach cancer cell lines; however, the SMAD4 3' UTR luciferase target assay results were obtained in HEK293 (human embryonic kidney) cells and not in stomach cancer cells [51]. Additionally, SMAD4 is a target of miR146a in various malignancies, such as leukemia [39] and hepatocellular carcinoma [52].

The results of the present study suggest that SMAD4 may have different implication between EBV-positive stomach cancer and EBV-negative stomach cancer.
SMAD4 nuclear loss, as detected by immunohistochemical staining in stomach cancer tissues, tended to be associated with poor survival rates in EBV-positive stomach cancer patients. Although the role of SMAD4 in the prognosis of EBV-positive stomach cancer patients has not been described previously, several reports have shown that SMAD4 loss is associated with poor prognosis in advanced stomach cancer patients [53-55]. In addition, SMAD4 functions as a tumor suppressor gene in stomach cancer $[53,56]$. The altered SMAD4 nuclear accumulation that
A

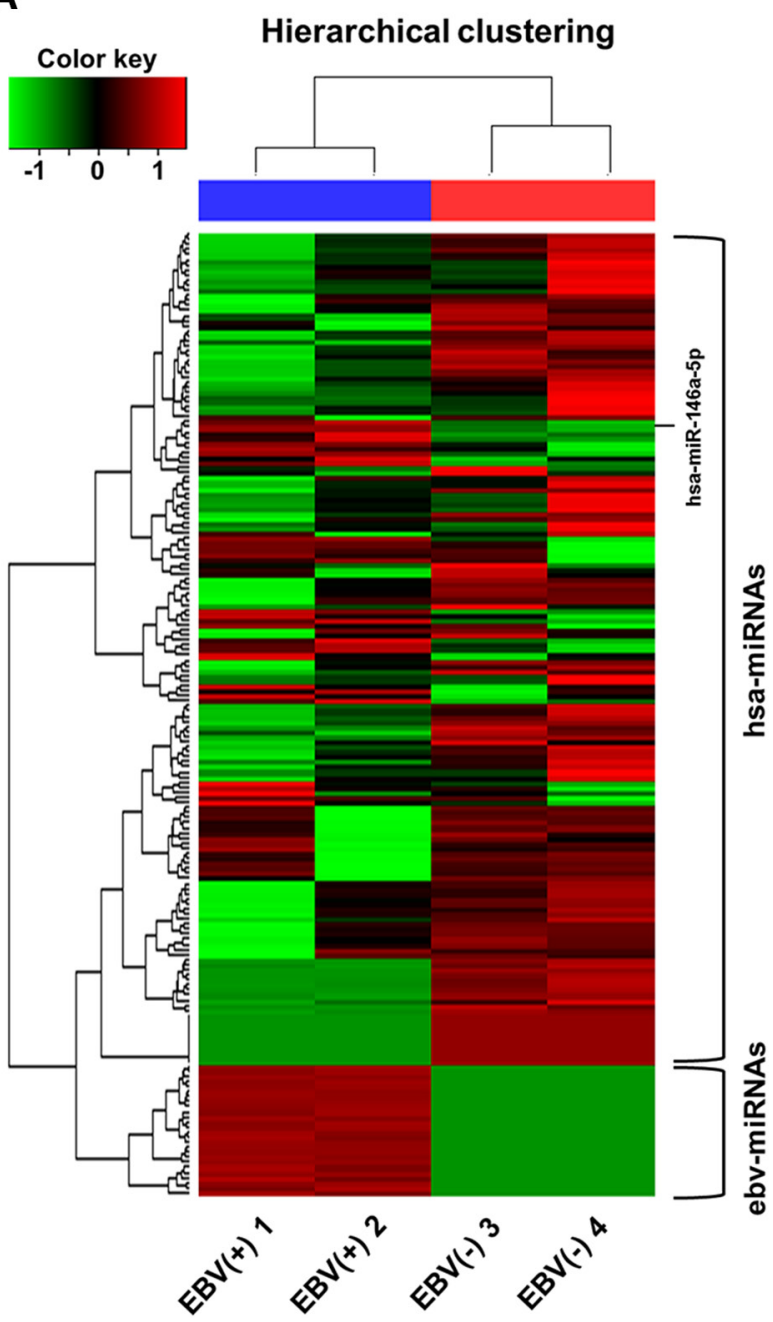

B

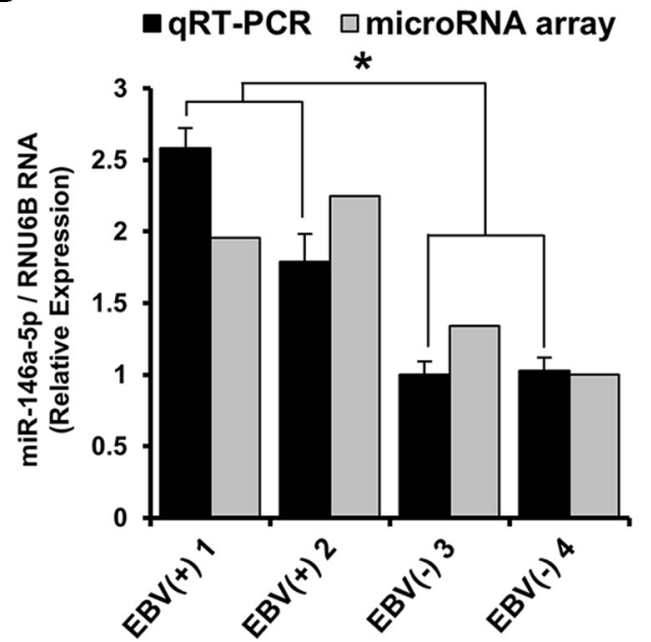

C

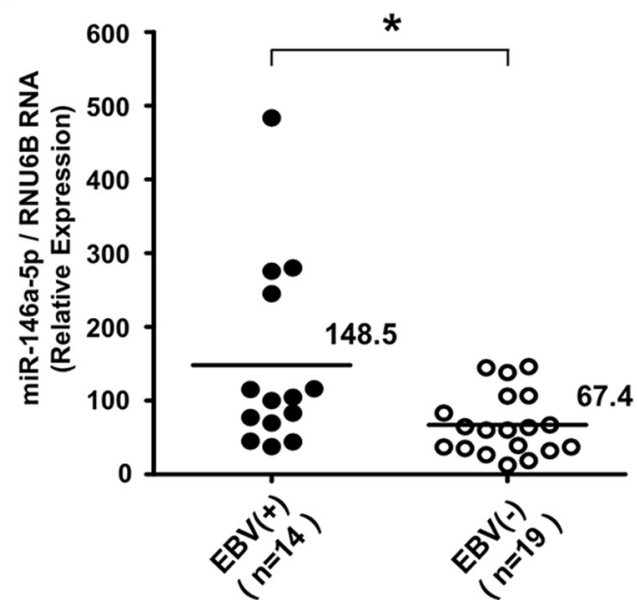

Figure 5: miRNA microarray expression profile and validation of miR-146a-5p level in surgically resected stomach cancer tissues. (A) Heat map and hierarchical clustering of miRNA expression showed a clear contrast between EBV-positive and EBVnegative cancer groups, with 31 miRNAs being upregulated including miR-146a-5p. Tissue samples are denoted as EBV(+) 1 and EBV(+) 2 for EBV-infected stomach cancer tissues and EBV(-) 3 and EBV(-) 4 for EBV-negative stomach cancer cases. The upper horizontal section represents human cellular miRNAs (hsa-miRNAs), and the lower horizontal section indicates EBV miRNAs (ebv-miRNAs). The red color indicates the expression of miRNAs in the sample, and green indicates absent or downregulated miRNAs. (B) TaqMan quantitative real-time RT-PCR was used to validate miRNA microarray data. miR-146a-5p levels were higher in EBV-positive stomach cancer tissues than in EBV-negative stomach cancer tissues $\left({ }^{*} P<0.05\right)$. (C) TaqMan quantitative real-time RT-PCR for miR-146a-5p was performed for an additional 14 cases of EBV-positive stomach cancer tissues and the other additional $19 \mathrm{EBV}$-negative stomach cancer tissues. The miR-146a-5p level in the EBV-positive stomach cancer group was higher than that in the EBV-negative stomach cancer group $(* P<0.05)$. RNU6B was used to normalize miR-146a-5p expression. 
was detected in the present study supports the idea that SMAD4 is active and affects transcriptional activity when localized to the nucleus $[43,45]$. With regard to a mechanism of SMAD4 nuclear loss, various mechanisms including dysregulation of nucleocytoplasmic shuttling, loss of heterozygosity, promoter hypermethylation and proteasome degradation are found in gastric carcinomas [53]. In particular, van Rees et al. reported that allelic loss of chromosome 18q (involving SMAD4 locus) was significantly less frequent in EBV-positive gastric carcinomas than in EBV-negative gastric carcinomas, which might be compensated for by a higher frequency of gene inactivation through promotor hypermethylation in EBV-positive gastric carcinomas [57].

In conclusion, EBV-encoded BARF1 promotes stomach cancer cell proliferation through a mechanism involving the upregulation of $\mathrm{NF} \kappa \mathrm{B}$ and miR-146a and the downregulation of SMAD4. These results may help explain the molecular mechanisms of EBV-infected stomach cancer progression. Moreover, SMAD4 loss may be useful as a negative prognostic factor in EBV-positive stomach cancer patients.

\section{MATERIALS AND METHODS}

\section{Cell culture and reagents}

SNU719 (stomach cancer cell line naturally infected with EBV), SNU601 and SNU216 (EBV- negative stomach cancer cell lines) were purchased from the Korean Cell Line Bank (Seoul, Korea). Another EBV-infected stomach cancer cell line, YCCEL1, was supplied by Dr. Rha [48]. Stable BARF1-expressing stomach cancer cells, SNU601 BARF1 [5] and SNU216 BARF1 cells were established. In brief, BARF1 was cloned from the naturally EBV-infected stomach cancer cell line SNU719. A pCMV-Tag 2B/flag/BARF1 plasmid was introduced into EBV-negative stomach cancer cells (SNU601 and SNU216) and transfectants were selected with G418 (Invitrogen, Carlsbad, CA, USA) (Supplementary Figure S1). Cells were maintained in RPMI 1640 medium (Gibco BRL, Rockville, MD, USA) supplemented with $10 \%$ fetal bovine serum and antibiotics (100 U/mL penicillin and streptomycin) at $37^{\circ} \mathrm{C}$ in a $5 \%$ $\mathrm{CO}_{2}$ atmosphere. Brefeldin A was used to inhibit protein transport from the endoplasmic reticulum to the Golgi apparatus (Sigma-Aldrich, St. Louis, MO, USA).

\section{RNA isolation and reverse transcription- polymerase chain reaction (RT-PCR)}

Total cellular RNA was prepared using an RNeasy Mini Kit (Qiagen, Hilden, Germany). Extracted RNA was treated for $20 \mathrm{~min}$ at $37^{\circ} \mathrm{C}$ with 10 units of DNase I (Roche, Basel, Switzerland) in the presence of RNase inhibitor (Roche) to remove residual genomic DNA. After inactivation at $75^{\circ} \mathrm{C}$ for $10 \mathrm{~min}$, RNA samples were purified with an RNeasy Mini Kit (Qiagen)

A



H\&E

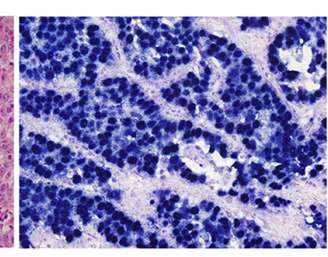

EBER

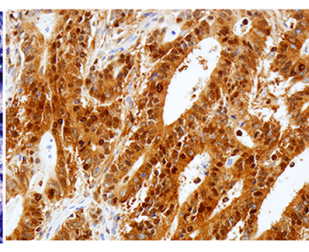

NFKB positive

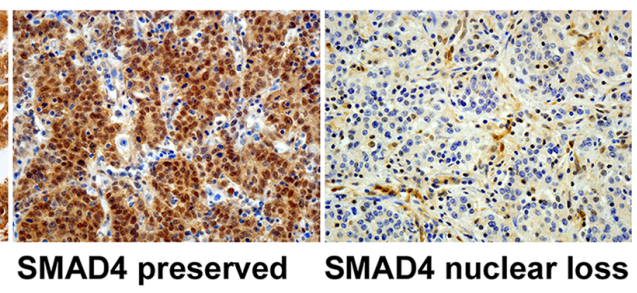

B
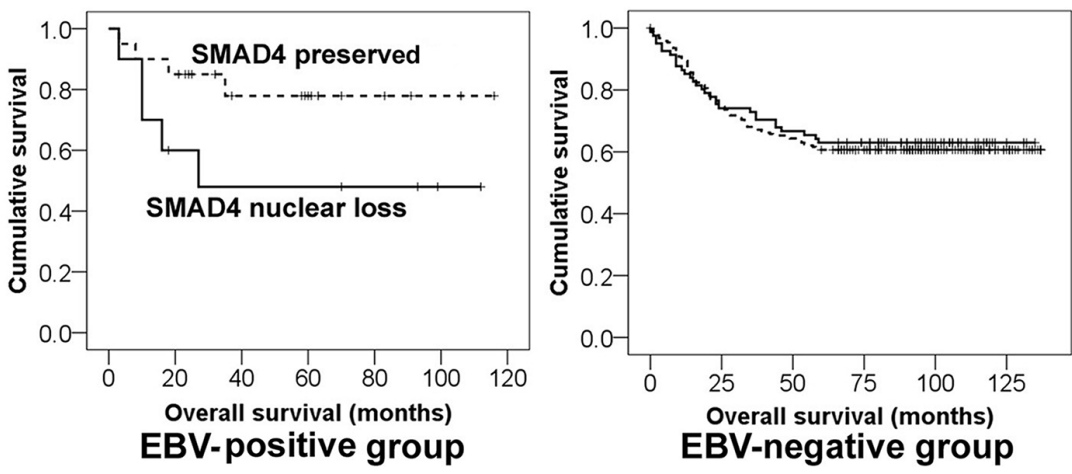

Figure 6: Different clinical implication of SMAD4 expression in EBV-positive and EBV-negative stomach cancer patients. (A) Representative microscopic images of the histologic features of EBV-positive stomach cancer tissues. In-situ hybridization for EBV-encoded small RNAs (EBER) showed black signals in almost all of the cancer cell nuclei. NFאB and SMAD4 immunohistochemistry was evaluated only nuclear staining of cancer cells. (B) Kaplan-Meier survival curves. The 'SMAD4 loss' group (solid line) tended to show a worse survival rate than the 'SMAD4 preserved' group (dotted line) among EBV-positive cancer patients $(P=0.08)$, whereas SMAD4 had no prognostic significance in EBV-negative patients. 
according to the manufacturer's recommendations. cDNA was synthesized from $1 \mu \mathrm{g}$ of total RNA (extracted from each sample) using a high fidelity RTPCR system. The forward and reverse primers for cDNA amplification were as follows: BARF1 forward, 5'-CGGGATCCATGGCCAGGTTCATC-3', and reverse, 5'-CCGCTCGAGTCATTGCGACAAGTAT-3'; GAPDH forward, 5'-GAGTCAACGGATTTGGTCGT-3', and reverse, 5'-TTGATTTTGGAGGGATCTCG-3'. The PCR conditions were as follows: 30 cycles each of denaturation at $94^{\circ} \mathrm{C}$ for $30 \mathrm{sec}$, annealing at $54^{\circ} \mathrm{C}$ for $30 \mathrm{sec}$, and extension $72^{\circ} \mathrm{C}$ for $1 \mathrm{~min}$. PCR products were analysed on $2 \%$ agarose gels.

\section{Immunofluorescence assay}

Cells seeded on coverslips were fixed for $10 \mathrm{~min}$ in $4 \%$ paraformaldehyde in $10 \mathrm{mmol} / \mathrm{L}$ piperazine- N,N bis (2-ethanesulfonic acid) (PIPES), pH 6.8, $10 \mathrm{mmol} / \mathrm{L}$ $\mathrm{NaCl}, 300 \mathrm{mmol} / \mathrm{L}$ sucrose, $3 \mathrm{mmol} / \mathrm{L} \mathrm{MgCl}_{2}$, and $2 \mathrm{mmol} / \mathrm{L}$ EDTA. Cells were permeabilized for $10 \mathrm{~min}$ in Tris-buffered saline (TBS) with $0.75 \%$ Triton X-100 and blocked for $10 \mathrm{~min}$ in $5 \%$ bovine serum albumin and $0.1 \%$ Triton X-100 in TBS. Cells were then incubated with antibodies against BARF1 (MAb 6F4, 1:100) [5] and SMAD4 (sc-7966, 1:200 Santa Cruz Biotechnology, Santa Cruz, CA, USA) and Alexa Fluor 488 goat antimouse $\operatorname{IgG}(\mathrm{H}+\mathrm{L})$ secondary antibody (Invitrogen). Nuclei were counterstained with 4',6-diamidino-2-phenylindole (DAPI) $(1 \mu \mathrm{g} / \mathrm{mL})$. Stained cells were visualized on a Zeiss Observer.Z1 fluorescence microscope or a Zeiss LSM710 confocal system (Carl Zeiss Meditec, Jena, Germany).

\section{Cell proliferation assay}

Cells were seeded into 96-well plates, treated as indicated, and incubated with the cell proliferation reagent Cell Counting Kit-8 (CCK-8; Dojindo Laboratories, Kumamoto, Japan) (10 $\mu \mathrm{L}$ of CCK-8) for $2 \mathrm{~h}$. Absorbance was measured at $450 \mathrm{~nm}$ on a spectrophotometer (Spectramax 190; Molecular Devices, Sunnyvale, CA, USA).

\section{Quantitative real-time RT-PCR}

Total cellular RNA including miRNA was isolated using the miRNeasy Mini Kit (Qiagen). miRNA cDNA synthesis was carried out with $10 \mathrm{ng}$ of total RNA from each sample using the TaqMan MicroRNA Reverse Transcription Kit (Ambion Life Technologies, Grand Island, NY, USA). TaqMan quantitative real-time RTPCR analysis was performed with an ABI 7900 Real-Time PCR System using the TaqMan miRNA assay (Applied Biosystems, Foster City, CA, USA) with the hsa-miR146a-5p (MIMAT0000449) primer set according to the manufacturer's protocol. RNU6b (Applied Biosystems) was used as a loading control in the TaqMan microRNA assay.

\section{siRNA, miRNA and plasmid transfection}

NFкB RelA-specific small interfering RNA (siRNA) and BARF1-specific siRNA (5'-GAGCCUCGGU CCAGAGAUUUU-3') were synthesized by Dharmacon RNA Technologies (Dharmacon, Lafayette, CO, USA). A scrambled siRNA (Dharmacon) containing a random sequence of nucleotides without known specificity was used as a negative control.

The miR-146a-5p mimic (hsa-miR-146a-5p; MC10722), miR-146a-5p inhibitor (hsa-miR-146a-5p; MH10722), and scrambled miRNA control (miR-control) were purchased from Ambion Applied Biosystems (Ambion Life Technologies). Transfections were performed using Lipofectamine 2000 (Invitrogen). Cells were transfected with miR-146a-5p mimic, miR-146a-5p inhibitor, or miR-control at a final concentration of $50 \mathrm{nM}$. The pCEP4-SMAD4 plasmid was obtained from the nonprofit plasmid repository Addgene (Cambridge, MA, USA) and was donated by Dr. Vogelstein [49].

\section{Western blot and densitometric analyses}

Protein concentrations were determined using a BCA protein assay kit (Merck, Gibbstown, NJ, USA). Proteins were separated by SDS-PAGE gels topped by a 5\% stacking gel and then transferred onto reinforced PVDF membranes (Millipore, Bedford, MA, USA). After incubation to block non-specific sites, blots were incubated overnight with primary antibodies against NFkB RelA (sc-109, 1:500, Santa Cruz Biotechnology), phospho-hCSF1 receptor (1:1000, Cell Signaling, Beverly, MA, USA), hCSF1 receptor (1:1000, Cell Signaling), SMAD2 (D43B4, 1:1000, Cell Signaling), SMAD3 (C67H9, 1:1000, Cell Signaling), and SMAD4 (B-8, sc7966, 1:1000, Santa Cruz Biotechnology) at $4^{\circ} \mathrm{C}$. Blots were then washed and incubated for $30 \mathrm{~min}$ at room temperature with a horseradish peroxidase-conjugated anti-mouse secondary antibody (Abcam, Cambridge, UK). The antigen-antibody complexes were visualized using ECL-staining (Amersham, Arlington Heights, IL, USA) and expose to X-ray film. Antibodies against transcription factor IIB (sc-23875, 1:2000, Santa Cruz Biotechnology) and $\beta$-actin (AC -15, 1:10000, Abcam) were used to verify equal loading and transfer of nuclear and total proteins, respectively. Developed films were imaged using a GS700 Imaging Densitometer (Bio-Rad, Hercules, CA, USA) and processed with Corel Photo Paint 7.0 to adjust image brightness and contrast. Densitometric evaluation was performed using Molecular Analyst Software (Bio-Rad), and normalization was performed using the corresponding controls depending on the specific analysis.

\section{Preparation of nuclear extracts}

Cells were resuspended in $100 \mu \mathrm{L}$ of lysis buffer A (10 mmol/L Tris, pH 8.0, $60 \mathrm{mmol} / \mathrm{L} \mathrm{NaCl}, 1 \mathrm{mmol} / \mathrm{L}$ 
EDTA, $1 \mathrm{mmol} / \mathrm{L}$ dithiothreitol, 0.1\% Nonidet P-40 and $1 \mathrm{mmol} / \mathrm{L}$ phenylmethylsulfonyl fluoride) and incubated on ice for $5 \mathrm{~min}$. Nuclear pellets were immediately washed in $1 \mathrm{~mL}$ of lysis buffer A without Nonidet P-40, centrifuged, and resuspended in $50 \mu \mathrm{L}$ of buffer B (200 $\mathrm{mmol} / \mathrm{L}$ HEPES, $\mathrm{pH} 7.9,0.75 \mathrm{mmol} / \mathrm{L}$ spermidine, $0.15 \mathrm{mmol} / \mathrm{L}$ spermine, $0.2 \mathrm{mmol} / \mathrm{L}$ EDTA, $2 \mathrm{mmol} / \mathrm{L}$ EGTA, $2 \mathrm{mmol} / \mathrm{L}$ dithiothreitol, 20\% glycerol, $1 \mathrm{mmol} / \mathrm{L}$ phenylmethylsulfonyl fluoride, and $0.4 \mathrm{M} \mathrm{NaCl}$ ).

\section{Luciferase activity assay}

To measure NFאB activity, cells were transfected with a cis-reporter plasmid containing the luciferase reporter gene linked to five tandem $\mathrm{NF \kappa B}$ binding sites $(0.8 \mu \mathrm{g}, \mathrm{pNF} \kappa \mathrm{B}$ Luc vector; Stratagene, La Jolla, CA, USA) using Lipofectamine 2000 (Invitrogen). A Renilla luciferase control reporter vector $(0.04 \mu \mathrm{g}, \mathrm{pRL}$ SV40:E2231; Promega, Madison, WI, USA) was cotransfected to normalize for transfection efficiency. After 72 h, luciferase activity was measured using a DualLuciferase Reporter Assay System kit (Promega) and was normalized to Renilla luciferase activity.

For the SMAD4 3'UTR assay, SNU601 BARF1 cells were seeded into 12-well plates one day before transfection, and then co-transfected with $0.8 \mu \mathrm{g}$ of pEZX-MT06 vector, containing either the SMAD4 3'UTR Renilla/firefly dualluciferase reporter plasmid (GeneCopoeia, Rockville, MD, USA) or empty vector (GeneCopoeia), along with $50 \mathrm{nM}$ of miR-146a-5p mimic or scrambled miRNA control (miRcontrol). After $48 \mathrm{~h}$, luciferase activity was measured using the dual-luciferase assay kit (Promega). Renilla luciferase activity was normalized to firefly luciferase activity. All assays were conducted in triplicate, and each transfection with reporter plasmid was carried out on a different day.

\section{miRNA microarray and data analysis}

Formalin-fixed paraffin-embedded tissue samples were cut with a microtome. Cut sections were placed in $1.5 \mathrm{~mL}$ tubes, and total RNA including miRNA was extracted using the miRNeasy FFPE kit (Qiagen) according to the manufacturer's instructions. The tissue lysate was treated with DNase I (Roche) to exclude DNA contamination. The miRNA expression profiles of stomach cancer tissue were established using the SurePrint G3 Human miRNA Microarray, Release 16.0, 8x60K (Agilent Technologies, Santa Clara, CA, USA), which is based on miRBase v16.0 (http://www.mirbase. org) and contains a total of 1205 human and 144 human viral miRNAs. All procedures were performed according to the manufacturer's recommendations. To analyse the differentially expressed miRNAs, quantile normalization was performed to standardize the data across the samples. Two cases of EBV-positive stomach cancer were grouped and analyzed against another two cases of EBV-negative stomach cancer using a fold-change cut-off of 1.5. Hierarchical clustering was then performed using the Euclidean distance metric and the complete linkage rule.

\section{RNA in-situ hybridization and immunohistochemistry of surgically resected stomach cancer tissues}

For patient prognosis study, we used formalinfixed paraffin-embedded tissues from 328 stomach cancer patients who had undergone surgery at the Seoul National University Boramae Hospital. In total, 30 cases of EBV-positive stomach cancer were included in the study: $13(4.2 \%)$ were from 311 consecutive surgeries that were performed between 2000 and 2005, and 17 were obtained from surgical cases in 2006 2010. For miRNA study, more recent formalin-fixed paraffin-embedded tissues should be needed. Accordingly, we selected stomach cancer tissues surgically resected in 2012, in which there were 14 EBV-positive and 19 EBV-negative cases. The retrospective study protocol was reviewed and approved by the Institutional Review Board of the Seoul National University Boramae Hospital under conditions of anonymity (IRB No. 20110318/06-2011-40/106 \& 20150907/16-2015-124/101).

In-situ hybridization for EBV-encoded small RNAs (EBERs) was performed with the Discovery XT automated IHC/ISH stainer (Ventana Medical Systems, Tucson, AZ, USA), according to the manufacturer's instructions. A fluorescein-conjugated EBV oligonucleotide probe for EBERs was used (Novocastra, Newcastle-upon-Tyne, UK). Black or dark navy-colored signals at the hybridization site, detected by light microscopy, were interpreted as EBV-carrying cells. Rarely, reactive lymphocytes showed black signals, but only signals within tumor cell nuclei were considered positive. All of EBV-positive cases showed black signals in almost all cancer cell nuclei.

Immunohistochemistry for $\mathrm{NF} \kappa \mathrm{B}$ and SMAD4 was performed with the Bond-Max automated immunostainer (Leica Microsystems, Nussloch, Germany). The tissue was incubated with anti-NFkB p65 (C-20) (sc-372, 1:150, Santa Cruz Biotechnology) or anti-SMAD4 antibody (B-8, sc7966, 1:200, Santa Cruz Biotechnology), and the antigen was detected with the Bond Polymer Refine Detection Kit DC9800 (Leica Microsystems). Immunohistochemical staining was evaluated by two pathologists (M.S.C. \& $\mathrm{S}-\mathrm{j}$. B.). Staining intensity was scored as 0 (no staining), $1+$ (weak intensity), 2+ (moderate intensity), or 3+ (strong intensity). For $\mathrm{NF} \kappa \mathrm{B}, 2+$ or $3+$ staining in $\geq 5 \%$ of cancer cell nuclei was considered positive [7, 8]. Regarding SMAD4, cases showing $2+$ or $3+$ staining in more than $10 \%$ of the cancer cell nuclei were deemed as 'SMAD4 preserved,' and the remaining cases were defined as 'SMAD4 loss' [58]. 


\section{Statistical analysis}

A chi-square test, Pearson's test, Kendall's Tau-b correlation analyses, Mann-Whitney U test and KaplanMeier survival analysis were performed with $\mathrm{IBM}^{\circledR}$ SPSS $^{\circledR}$ Statistics 20.0 (IBM Inc., Chicago, IL, USA). A $P$ value $<0.05$ was considered statistically significant.

\section{ACKNOWLEDGMENTS AND FUNDING}

This work was supported by Basic Science Research Program through the National Research Foundation of Korea (NRF) funded by the Ministry of Education (2016R1D1A1B01010316) and a grant (11-184) from the Asan Institute for Life Sciences, Asan Medical Center, Seoul, Korea (JHW).

\section{CONFLICTS OF INTEREST}

The authors declared no conflicts of interest.

\section{REFERENCES}

1. Bass AJ, Thorsson V, Shmulevich I, Reynolds SM, Miller M, Bernard B, Hinoue T, Laird PW, Curtis C, Shen H, Weisenberger DJ, Schultz N, Shen R, et al. Cancer Genome Atlas Research Network. Comprehensive molecular characterization of gastric adenocarcinoma. Nature. 2014; 513:202-209.

2. Epstein MA, Achong BG, Barr YM. Virus particles in cultured lymphoblasts from Burkitt's lymphoma. Lancet. 1964; 1:702-703.

3. Longnecker RM, Kieff E, Cohen JI. Epstein-Barr virus. In Fields virology, (6th edn), Knipe DM, Howley PM (eds). Lippincott-Williams and Wilkins: Philadelphia, PA, USA, 2013; 1898-1959.

4. Burke AP, Yen TS, Shekitka KM, Sobin LH. Lymphoepithelial carcinoma of the stomach with EpsteinBarr virus demonstrated by polymerase chain reaction. Mod Pathol. 1990; 3:377-380.

5. Chang MS, Kim DH, Roh JK, Middeldorp JM, Kim YS, Kim S, Han S, Kim CW, Lee BL, Kim WH, Woo JH. Epstein-Barr virus-encoded BARF1 promotes proliferation of gastric carcinoma cells through regulation of NF-kappaB. J Virol. 2013; 87:10515-10523.

6. Nishikawa J, Yoshiyama H, Iizasa H, Kanehiro Y, Nakamura M, Nishimura J, Saito M, Okamoto T, Sakai K, Suehiro Y, Yamasaki T, Oga A, Yanai H, et al. EpsteinBarr virus in gastric carcinoma. Cancers (Basel). 2014; 6:2259-2274.

7. Chang MS, Lee HS, Jung EJ, Kim CW, Lee BL, Kim WH. Cell-cycle regulators, bcl-2 and NF-kappaB in EpsteinBarr virus-positive gastric carcinomas. Int J Oncol. 2005; 27:1265-1272.
8. Jeong JY, Woo JH, Kim YS, Choi S, Lee SO, Kil SR, Kim CW, Lee BL, Kim WH, Nam BH, Chang MS. Nuclear factor-kappa B inhibition reduces markedly cell proliferation in Epstein-Barr virus-infected stomach cancer, but affects variably in Epstein-Barr virus-negative stomach cancer. Cancer Invest. 2010; 28:113-119.

9. Chang MS, Lee HS, Kim CW, Kim YI, Kim WH. Clinicopathologic characteristics of Epstein-Barr virusincorporated gastric cancers in Korea. Pathol Res Pract. 2001; 197:395-400.

10. Shinozaki-Ushiku A, Kunita A, Fukayama M. Update on Epstein-Barr virus and gastric cancer (review). Int J Oncol. 2015; 46:1421-1434.

11. Gulley ML. Genomic assays for Epstein-Barr virus-positive gastric adenocarcinoma. Exp Mol Med. 2015; 47:e134.

12. Lee HS, Chang MS, Yang HK, Lee BL, Kim WH. EpsteinBarr virus-positive gastric carcinoma has a distinct protein expression profile in comparison with Epstein-Barr virusnegative carcinoma. Clin Cancer Res. 2004; 10:1698-1705.

13. van Beek J, zur Hausen A, Klein Kranenbarg E,van de Velde CJ, Middeldorp JM, van den Brule AJ, Meijer CJ, Bloemena E. EBV-positive gastric adenocarcinomas: a distinct clinicopathologic entity with a low frequency of lymph node involvement. J Clin Oncol. 2004; 22:664-670.

14. Fukayama M, Hayashi Y, Iwasaki Y, Chong J, Ooba T, Takizawa T, Koike M, Mizutani S, Miyaki M, Hirai K. Epstein-Barr virus-associated gastric carcinoma and Epstein-Barr virus infection of the stomach. Lab Invest. 1994; 71:73-81.

15. Kang GH, Lee S, Kim WH, Lee HW, Kim JC, Rhyu MG, Ro JY. Epstein-Barr virus-positive gastric carcinoma demonstrates frequent aberrant methylation of multiple genes and constitutes $\mathrm{CpG}$ island methylator phenotype-positive gastric carcinoma. Am J Pathol. 2002; 160:787-794.

16. Geddert H, zur Hausen A, Gabbert HE, Sarbia M. EBVinfection in cardiac and non-cardiac gastric adenocarcinomas is associated with promoter methylation of p16, p14 and APC, but not hMLH1. Anal Cell Pathol (Amst). 2010; 33:143-149.

17. Mohidin TB, Ng CC. BARF1 gene silencing triggers caspase-dependent mitochondrial apoptosis in Epstein-Barr virus-positive malignant cells. J Biosci. 2015; 40:41-51.

18. Hoebe EK, Le Large TY, Greijer AE, Middeldorp JM. BamHI-A rightward frame 1, an Epstein-Barr virus-encoded oncogene and immune modulator. Rev Med Virol. 2013; 23:367-383.

19. zur Hausen A, Brink AA, Craanen ME, Middeldorp JM, Meijer CJ, van den Brule AJ. Unique transcription pattern of Epstein-Barr virus (EBV) in EBV-carrying gastric adenocarcinomas: expression of the transforming BARF1 gene. Cancer Res. 2000; 60:2745-2748.

20. Wei MX, Ooka T. A transforming function of the BARF1 gene encoded by Epstein-Barr virus. EMBO J. 1989; 8:2897-2903. 
21. Strockbine LD, Cohen JI, Farrah T, Lyman SD, Wagener F, DuBose RF, Armitage RJ, Spriggs MK. The EpsteinBarr virus BARF1 gene encodes a novel, soluble colonystimulating factor-1 receptor. J Virol. 1998; 72:4015-4021.

22. Hoebe EK, Le Large TY, Tarbouriech N, Oosterhoff D, De Gruijl TD, Middeldorp JM, Greijer AE. Epstein-Barr virusencoded BARF1 protein is a decoy receptor for macrophage colony stimulating factor and interferes with macrophage differentiation and activation. Viral Immunol. 2012; 25:461470.

23. Ondondo B, Morgan DJ. Fukayama M, Ushiku T. The B subunit of Escherichia coli enterotoxin helps control the in vivo growth of solid tumors expressing the Epstein-Barr virus latent membrane protein 2A. Cancer Med. 2015; $4: 457-471$.

24. Hino R, Uozaki H, Inoue $Y$, Shintani $Y$, Ushiku T, Sakatani T, Takada K, Fukayama M. Survival advantage of EBV-associated gastric carcinoma: survivin up-regulation by viral latent membrane protein 2A. Cancer Res. 2008; 68:1427-1435.

25. Zhang YW, Zhao XX, Tan C, Zhang ZG, Jiang Y, Chen JN, Wei HB, Xue L, Li HG, Du H, Shao CK. Epstein-Barr virus latent membrane protein $2 \mathrm{~A}$ suppresses the expression of HER2 via a pathway involving TWIST and YB-1 in EpsteinBarr virus-associated gastric carcinomas. Oncotarget. 2015; 6:207-220. doi: 10.18632/oncotarget.2702.

26. Tworkoski K, Raab-Traub N. LMP1 promotes expression of insulin-like growth factor 1 (IGF1) to selectively activate IGF1 receptor and drive cell proliferation. J Virol. 2015; 89:2590-2602.

27. Wu WK, Lee CW, Cho CH, Fan D, Wu K, Yu J, Sung JJ. MicroRNA dysregulation in gastric cancer: a new player enters the game. Oncogene. 2010; 29:5761-5771.

28. Bartel DP. MicroRNAs: genomics, biogenesis, mechanism, and function. Cell. 2004; 116:281-297.

29. Saba R, Sorensen DL, Booth SA. MicroRNA-146a: A dominant, negative regulator of the innate immune response. Front Immunol. 2014; 5:578.

30. Jiang C, Chen X, Alattar M, Wei J, Liu H. MicroRNAs in tumorigenesis, metastasis, diagnosis and prognosis of gastric cancer. Cancer Gene Ther. 2015; 22:291-301.

31. Yang GD, Huang TJ, Peng LX, Yang CF, Liu RY, Huang HB, Chu QQ, Yang HJ, Huang JL, Zhu ZY, Qian CN, Huang BJ.Epstein-Barr Virus-encoded LMP1 upregulates microRNA-21 to promote the resistance of nasopharyngeal carcinoma cells to cisplatin-induced apoptosis by suppressing PDCD4 and Fas-L. PLoS One. 2013; 8:e78355.

32. Yang GD, Huang TJ, Peng LX, Yang CF, Liu RY, Huang HB, Chu QQ, Yang HJ, Huang JL, Zhu ZY, Qian CN, Huang BJ. Expression of miRNA-146a in nasopharyngeal carcinoma is upregulated by Epstein-Barr virus latent membrane protein 1. Oncol Rep. 2012; 28:1237-1242.

33. Cameron JE, Yin Q, Fewell C, Lacey M, McBride J, Wang X, Lin Z, Schaefer BC, Flemington EK. Epstein-Barr virus latent membrane protein 1 induces cellular microRNA
miR-146a, a modulator of lymphocyte signaling pathways. J Virol .2008; 82:1946-1958.

34. Forte E, Salinas RE, Chang C, Zhou T, Linnstaedt SD, Gottwein E, Jacobs C, Jima D, Li QJ, Dave SS, Luftig MA. The Epstein-Barr virus (EBV)-induced tumor suppressor microRNA MiR-34a is growth promoting in EBV-infected B cells. J Virol. 2012; 86:6889-6898.

35. Motsch N, Pfuhl T, Mrazek J, Barth S, Grässer FA. EpsteinBarr virus-encoded latent membrane protein 1 (LMP1) induces the expression of the cellular microRNA miR-146a. RNA Biol. 2007; 4:131-137.

36. Li G, Wu Z, Peng Y, Liu X, Lu J, Wang L, Pan Q, He ML, Li XP. MicroRNA-10b induced by Epstein-Barr virusencoded latent membrane protein-1 promotes the metastasis of human nasopharyngeal carcinoma cells. Cancer Lett. 2010; 299:29-36.

37. Taganov KD, Boldin MP, Chang KJ, Baltimore D. NFkappaB-dependent induction of microRNA miR-146, an inhibitor targeted to signaling proteins of innate immune responses. Proc Natl Acad Sci U S A. 2006; 103:12481-12486.

38. Nahid MA, Pauley KM, Satoh M, Chan EK. miR-146a is critical for endotoxin-induced tolerance: Implication innate immunity. J Biol Chem. 2009; 284:34590-34599.

39. Zhong H, Wang HR, Yang S, Zhong JH, Wang T, Wang C, Chen FY. Targeting Smad4 links microRNA-146a to the TGF-beta pathway during retinoid acid induction in acute promyelocytic leukemia cell line. Int J Hematol. 2010; 92:129-135.

40. He Y, Huang C, Sun X, Long XR, Lv XW, Li J. MicroRNA146a modulates TGF-beta1-induced hepatic stellate cell proliferation by targeting SMAD4. Cell Signal. 2012; 24:1923-1930.

41. Mori N, Morishita M, Tsukazaki T, Yamamoto N. Repression of Smad-dependent transforming growth factorbeta signaling by Epstein-Barr virus latent membrane protein 1 through nuclear factor-kappaB. Int J Cancer. 2003; 105:661-668.

42. Grau AM, Datta PK, Zi J, Halder SK, Beauchamp RD. Role of Smad proteins in the regulation of NF-kappaB by TGFbeta in colon cancer cells. Cell Signal. 2006; 18:1041-1050.

43. Heldin $\mathrm{CH}$, Miyazono K, ten Dijke P. TGF-beta signaling from cell membrane to nucleus through SMAD proteins. Nature. 1997; 390:465-471.

44. Denicourt C, Dowdy SF. Another twist in the transforming growth factor $\beta$-induced cell-cycle arrest chronicle. Proc Natl Acad Sci U S A. 2003; 100:15290-15291.

45. Fink SP, Mikkola D, Willson JK, Markowitz S. TGF- $\beta$ induced nuclear localization of Smad2 and Smad3 in Smad4 null cancer cell lines. Oncogene. 2003; 22:1317-1323.

46. Prokova V, Mosialos G, Kardassis D. Inhibition of transforming growth factor beta signaling and Smaddependent activation of transcription by the latent membrane protein 1 of Epstein-Barr virus. J Biol Chem. 2002; 277:9342-9350. 
47. Wood VH, O'Neil JD, Wei W, Stewart SE, Dawson CW, Young LS. Epstein-Barr virus-encoded EBNA1 regulates cellular gene transcription and modulates the STAT1 and TGFbeta signaling pathways. Oncogene. 2007; 26:41354147.

48. Kim do N, Seo MK, Choi H, Kim SY, Shin HJ, Yoon AR, Tao Q, Rha SY, Lee SK. Characterization of naturally Epstein-Barr virus-infected gastric carcinoma cell line YCCEL1. J Gen Virol. 2013; 94:497-506.

49. Riggins GJ, Thiagalingam S, Rozenblum E, Weinstein CL, Kern SE, Hamilton SR, Willson JK, Markowitz SD, Kinzler KW, Vogelstein B. Mad-related genes in the human. Nat Genet. 1996; 13:347-349.

50. Landais I, Pelton C, Streblow D, DeFilippis V, McWeeney S, Nelson JA. Human cytomegalovirus miR-UL112-3p targets TLR2 and modulates the TLR2/IRAK1/NFkB signaling pathway. PLoS Pathog 2015; 11:e1004881.

51. Xiao B, Zhu ED, Li N, Lu DS, Li W, Li BS, Zhao YL, Mao XH, Guo G, Yu PW, Zou QM. Increased miR-146a in gastric cancer directly targets SMAD4 and is involved in modulating cell proliferation and apoptosis. Oncol Rep. 2012; 27:559-566.

52. Tomokuni A,Eguchi H, Tomimaru Y, Wada H, Kawamoto K, Kobayashi S, Marubashi S, Tanemura M, Nagano H, Mori M, Doki Y. miR-146a suppresses the sensitivity to interferon-alpha in hepatocellular carcinoma cells. Biochem Biophys Res Commun. 2011; 414:675-680.
53. Wang LH, Kim SH, Lee JH, Choi YL, Kim YC, Park TS, Hong YC, Wu CF, Shin YK. Inactivation of SMAD4 tumor suppressor gene during gastric carcinoma progression. Clin Cancer Res. 2007; 13:102-110.

54. Xiangming C, Natsugoe S, Takao S, Hokita S, Ishigami S, Tanabe G, Baba M, Kuroshima K, Aikou T. Preserved Smad4 expression in the transforming growth factor beta signaling pathway is a favorable prognostic factor in patients with advanced gastric cancer. Clin Cancer Res. 2001; 7:277282.

55. Kim YH, Lee HS, Lee HJ, Hur K, Kim WH, Bang YJ, Kim SJ, Lee KU, Choe KJ, Yang HK. Prognostic significance of the expression of SMAD4 and Smad7 in human gastric carcinomas. Ann Oncol. 2004; 15:574-580.

56. Shi Y, Hata A, Lo RS, Massagué J, Pavletich NP. A structural basis for mutational inactivation of the tumor suppressor Smad4. Nature. 1997; 388:87-93.

57. van Rees BP, Caspers E, zur Hausen A, van den Brule A, Drillenburg P, Weterman MAJ, Offerhaus GJA. Different pattern of alleic loss in Epstein-Barr virus-positive gastric cancer with emphasis on the p53 tumor suppressor pathway. Am J Pathol 2002; 161:1207-1213. 